\title{
Rodent Models Assessing Mammary Tumor Prevention by Soy or Soy Isoflavones
}

\author{
Roger A. Moorehead $(\mathbb{D}$ \\ Department of Biomedical Sciences, Ontario Veterinary College, University of Guelph, Guelph, ON N1G2W1, \\ Canada; rmoorehe@uoguelph.ca
}

Received: 12 April 2019; Accepted: 9 July 2019; Published: 26 July 2019

\begin{abstract}
While epidemiological studies performed in Asian countries generally show that high levels of dietary soy are associated with reduced breast cancer risk, studies in Western countries have typically failed to show this correlation. In an attempt to model the preventative actions of soy on mammary tumor development, rodent models have been employed. Thirty-four studies were identified that evaluated the impact of soy products or purified soy isoflavones on mammary tumor initiation (studies evaluating established mammary tumors or mammary tumor cell lines were not included) and these studies were separated into mammary tumors induced by chemical carcinogens or transgenic expression of oncogenes based on the timing of soy administration. Regardless of when soy-based diets or purified isoflavones were administered, no consistent protective effects were observed in either carcinogen-induced or oncogene-induced mammary tumors. While some studies demonstrated that soy or purified isoflavones could reduce mammary tumor incidence, other studies showed either no effect or tumor promoting effects of soy products or isoflavones. Most importantly, only five studies found a decrease in mammary tumor incidence and six studies observed a decrease in tumor multiplicity, two relevant measures of the tumor preventative effects of soy or isoflavones. The variable outcomes of the studies examined were not completely surprising given that few studies employed the same experimental design. Future studies should be carefully designed to more accurately emulate soy consumption observed in Asian cultures including lifetime exposure to less refined soy products and potentially the incorporation of multigenerational feeding studies.
\end{abstract}

Keywords: soy; isoflavones; mammary tumor prevention; rodent models; chemical carcinogens; transgenic mice

\section{Introduction}

It has been estimated that approximately $35 \%$ of human cancers are preventable through changes in lifestyle such as maintaining a healthy body weight, eliminating alcohol and tobacco, and adhering to cancer screening guidelines [1]. One lifestyle change that has been specifically associated with breast cancer is the consumption of high levels of dietary soy. Several epidemiologic studies found that women from cultures consuming high levels of dietary soy have an $\sim 3$-fold reduced risk of developing breast cancer compared to women that only consume small amounts of soy [2-6]. Several meta-analyses of the epidemiologic studies found that high consumption of soy reduced the risk of breast cancer in both pre- and post-menopausal women in studies performed on Asian populations but not on women from Western countries [6-8]. A 2019 meta-analysis found that individuals consuming high levels of isoflavones had similar breast cancer rates as those consuming low levels of isoflavones. When this meta-analysis only evaluated studies that reported the intake of soy foods, individuals consuming high levels of soy foods had a significant reduction in breast cancer risk compared to those in the low soy-food consumption group [9]. Therefore, although most studies suggest that consuming high levels of dietary soy may reduce the risk of developing breast cancer, there is no clear consensus. 
However, some of this variation may stem from the population examined, types of soy products consumed (refined vs unrefined, fermented vs unfermented, and soy foods vs isoflavones), as well as the timing and duration of soy consumption. Ideally, randomized human prevention trials should be performed; however, these types of studies would take decades to complete, may raise ethical concerns of feeding developing fetuses or newborns specialized diets without their consent, and it would be difficult to maintain compliance to specific diets for such a long duration.

Since human randomized clinical trials are not feasible, animal models have been utilized with the most common being rodent models. Rodent mammary glands share features with the human breast including epithelial-lined ducts surrounded by myoepithelial cells, fibroblast and stroma [10]. In addition, both the mouse mammary gland and human breast respond to similar growth factors, cytokines and hormones during pubertal ductal development, alveologenesis and involution [10]. There are, however, differences in human and rodent mammary glands including the number of mammary glands, increased density of fibrous tissue in human breasts as well as more complex lobulo-alveolar structures in human breasts [11].

This review focuses on rodent models designed to assess the preventative actions of dietary soy products or purified isoflavones and includes papers published since 1995. For studies prior to 1995, please see the review by Barnes [12]. The efficacy of dietary soy or purified isoflavones in reducing breast cancer progression or tumor recurrence has been investigated but is beyond the scope of this review. While it is possible that soy isoflavones impact tumor cell progression or recurrence using similar mechanisms as those that prevent mammary tumor initiation, it is also possible that these tumor stages are regulated by distinct mechanisms and thus this review has focused on soy's impact on tumor initiation and not progression or recurrence.

\section{Soy and Isoflavones}

Soy products are derived from soybeans and contain a number of compounds including protease inhibitors, phytosterols, saponins, and phytoestrogens known as isoflavones. Most of the work has focused on the isoflavone component of soybeans and the main isoflavones are genistein, daidzein and glycitein [13]. Isoflavones have chemical structures similar to mammalian estrogens and thus can bind to estrogen receptor- $\alpha(E R \alpha)$ and ER $\beta$ [14-16]. The affinity of isoflavones for ER $\alpha$ and ER $\beta$ is also different with isoflavones preferentially binding to ER $\beta$ [17-20]. However, soy isoflavones have relatively weak estrogenic activity compared to endogenous estrogens [21,22] and thus, it is thought that dietary isoflavones partially impede endogenous estrogen signaling $[14,23,24]$. Since elevated lifetime estrogen exposure is a breast cancer risk factor [25], soy isoflavones may reduce breast cancer risk by suppressing the effects of endogenous estrogen. In addition to altering estrogen signaling, soy isoflavones have been reported to decrease lipid peroxidation and oxidative DNA damage through their antioxidant properties [24,26-28], promote apoptosis [26,29], inhibit angiogenesis [27,30-32] and regulate DNA methylation [33]. It should be noted that most mechanistic studies of soy isoflavones are performed in vitro using isoflavone concentrations exceeding 25 micromolar, while circulating levels of isoflavones in rodents and humans consuming soy-rich diets are typically less than 1-5 micromolar [29,31,32,34-36]. Moreover, in vitro studies cannot account for modifications of isoflavones during normal metabolism that can influence the relative abundance of isoflavone metabolites and their bioactivity [37]. While most of the studies have focused on the isoflavone components of soy, other soybean components such as protease inhibitors, phytosterols and saponins that may also influence breast cancer risk [38-40].

Not all sources of dietary soy are equal. Asian cultures typically consume minimally processed soybeans and more fermented soy products such as miso or tempeh where isoflavones are primarily in their aglycone form (genistein, daidzein and glycitein) [41]. In contrast, Western societies typically consume non-fermented soy products such as soy milk or tofu which contains isoflavones primarily in their glucosides form (genistin, daidzin and glycitin). In addition, soy products in North America often undergo extensive extraction and purification processes producing a product known as isolated soy 
protein (ISP) or soy protein isolate, which lacks most of the carbohydrates and fiber, leaving a product that is approximately $90 \%$ protein. This processing also influences the levels of isoflavones [42-44] and removes a number of soy compounds including protease inhibitors, phytosterols and saponins that may alter the protective properties associated with soybeans [42].

\section{Rodent Mammary Tumor Models}

One of the first and most common rodent models used to evaluate the impact of soy isoflavones on mammary tumor develop is the administration of 7,12-Dimethylbenzathracene (DMBA) to rats. DMBA is typically given as a single dose to pubertal female rats through injection or oral gavage and tumor incidence is close to $100 \%$ with tumor onset ranging from 8-21 weeks, depending on the concentration of DMBA administered [45]. Mammary tumors induced by DBMA are typically minimally invasive but remain hormone-dependent and thus are reasonable models for estrogen dependent breast cancers [46]. Other chemical carcinogens have also been used including $N$-methyl- $N$-nitrosourea (NMU) and ethyl methanesulfonate (EMS), which are typically provided as a single administration to pubertal female rats and 2-amino-1-methyl-6-penylimidazo[4-b]pyridine (PhIP) is administered orally to rats four times per week for two weeks. Although chemically induced rat mammary tumor models share features with human breast cancer they frequently induce mutations in Hras [47-50], a phenomenon not frequently observed in human breast cancers. However, a more recent study evaluating genetic alterations induced by DMBA in mice frequently observed mutations in Pi3kca and Pten, two relevant human breast cancer genes [51]. Chemical carcinogens are used less frequently in mice as mice are more resistant to chemically induced mammary tumors than rats and require multiple doses of chemical carcinogens [51].

With the generation of genetically modified mice, alterations in specific oncogenes or tumor suppressor genes became possible. The most widely used transgenic mammary tumor model is MMTV-neu transgenic mice. MMTV-neu mice express elevated levels of EbbB2 (rodent equivalent of human HER-2) in mammary epithelial cells as well as other epithelial cells where the mouse mammary tumor virus (MMTV) promoter is expressed [52-54]. MMTV-neu mice develop mammary tumors with a median onset of 5-10 months [55-57] and these tumors have characteristics similar to human HER2+ tumors [58]. Another MMTV driven transgene that induces mammary tumor development is Wnt1. MMTV-Wnt1 transgenic mice develop mammary tumors expressing both luminal and myoepithelial genes and cluster most closely with normal human breast tissue [58]. One limitation with MMTV-driven transgenes is that the oncogene is expressed at low levels throughout the animal's lifespan. The MMTV promoter is responsive to steroid hormones [59-62] and thus its activity is highest during puberty and gestation with low levels of MMTV promoter activity prior to puberty. As it remains unclear when the initiating events for breast cancer occur, expression of an oncogene at all developmental stages may or may not accurately reflect oncogene expression in humans.

Two non-MMTV-driven transgenes have been used to study the impact of dietary soy on mammary tumor development: C(3)1/SV40 and Mt- $h G H$. C(3)1/SV40 transgenic mice express the simian virus 40 large $\mathrm{T}$ antigen driven by the rat prostatic steroid binding protein C3(1) $5^{\prime}$-flanking sequence. Female mice develop mammary tumors by 4 months of age and male mice develop prostate tumors by 1 year of age [63]. Mammary tumors from C(3)1/SV40 transgenic mice share characteristics with human basal-like tumors [58]. Mt $h$ GH transgenic mice express elevated levels of human growth hormone driven by a murine metallothionein promoter. These mice develop mammary tumors by $27-43$ weeks of age [64]. Gene expression analysis has not been performed on these mammary tumors but the authors describe the tumors as malignant papillary adenocarcinomas [64].

In addition to the transgenic mice describe above, MTB-IGFIR transgenic mice [65] have also been used to investigate soy isoflavone's impact on mammary tumorigenesis [66]. MTB-IGFIR transgenic mice overexpress the human insulin-like growth factor receptor (IGF-IR) in mammary epithelial cells in a doxycycline-inducible manner [65]. Mammary tumors rapidly develop in 100\% of the mice and these mammary tumors cluster most closely with human basal-like breast cancers [67]. The MTB-IGFIR 
transgenic mice overcome one of the limitations of constitutive transgenic models (i.e., MMTV-driven transgenes) in that the IGF-IR transgene is only expressed when doxycycline is present and thus transgene expression can be initiated in pubertal or adult mice $[65,68]$.

\section{Timing of Soy Exposure}

A key difference in the studies evaluating the impact of soy isoflavones on mammary tumor development in rodent models is the timing of soy isoflavone administration. Most of the early studies and even some of the more recent studies initiate the feeding of soy diets or purified isoflavones in postnatal rodents. This experimental approach would presumably emulate the human situation where children or adolescents switch their diet to one containing high levels of soy. However, Asian cultures, where reduced breast cancer rates are observed, would presumably consume high levels of soy at all stages of life including during pregnancy and lactation as well as during childhood, adolescence and adulthood. Therefore, lifetime exposure (gestation, lactation and postnatal development) may more accurately model the isoflavone consumption of cultures with reduced breast cancer rates.

Given the potential importance of the timing of soy exposure this review has been organized into two main sections: mammary tumor development following postnatal soy/isoflavone exposure, and mammary tumor development following lifetime soy/isoflavone exposure. There were also four studies that investigated soy exposure only during the perinatal developmental window, which have been included in this review.

\section{Mammary Tumor Development Following Postnatal Soy Isoflavone Administration}

Twenty-three studies were identified that evaluated mammary tumorigenesis following the administration of soy-based diets or purified isoflavones during postnatal development; fourteen using chemical carcinogens in rats [69-82] and nine using transgenic mice [83-91]. For this review, postnatal administration was defined by the initiation of soy-based diets or isoflavones at weaning or later and the design of these studies and the main findings are summarized in Table 1. The impact of soy isoflavones on mammary tumor development were highly variable. This was not completely surprising given the differences in (1) the chemical carcinogen or oncogene used, (2) the source and concentration of soy products or purified isoflavones, and (3) the timing of soy/isoflavone administration. Within the 14 chemical carcinogen studies, 8 found that soy/isoflavones had some protective effect against mammary tumorigenesis (tumor incidence, latency, multiplicity or size) [70-74,76,79,82] but only 2 of these studies observed a truly protective effect against mammary tumor development as measured as a significant decrease in tumor incidence [71,72], while 3 studies demonstrated a significant reduction in tumor multiplicity $[74,76,79]$. Three of the studies using chemical carcinogens found that soy/isoflavones promoted mammary tumor incidence, multiplicity, or size $[72,75,80]$.

The findings were also highly variable in the transgenic mouse models with four of the nine studies showing at least some protective effect against mammary tumorigenesis (tumor incidence, latency, multiplicity or size) [83,86-88], with two of these studies observing a significant decrease in tumor incidence $[83,88]$. Three of the studies found no effect $[84,89,91]$ and three of the studies found that soy isoflavones promoted at least one mammary tumor property $[83,85,90]$. The transgenic data was more difficult to evaluate as often other characteristics (i.e., high fat diet, estrogen levels) and different concentrations of isoflavones were assessed in the same study. For example, the study by Zhang et al. [83] assessed the impact of soy on mammary tumor development in MMTV-neu mice with low (ovariectomized mice), normal or high (estradiol injection) levels of estrogen. In this study it was observed that diets high in soy increased tumor incidence in the low estrogen group, but the soy diet reduced tumor incidence in the high estrogen group (explaining why this study is referenced as soy-based diets having demonstrated both tumor protective and tumor promoting effects in the discussion above). 
Table 1. Postnatal Soy/Isoflavone Administration.

\begin{tabular}{|c|c|c|c|c|}
\hline Species & Isoflavone Diet/Timing & Tumor Inducer & Main Finding & Refs \\
\hline rat & $\begin{array}{l}0.25 \mathrm{~g} / \mathrm{kg} \text { or } 1 \mathrm{~g} / \mathrm{kg} \text { of daidzein or genistein separately } \\
\text { or } 1 \mathrm{~g} / \mathrm{kg} \text { of both daidzein and genistein, PND35-EOS }\end{array}$ & $\begin{array}{l}1 \text { oral dose, } 80 \mathrm{mg} / \mathrm{kg} \text { body weight } \\
\text { DMBA at PND50 }\end{array}$ & No significant difference in tumor incidence or size compared to control diet & [69] \\
\hline rat & $\begin{array}{l}500 \text { ppm genistein in diet, PND15-30, PND15-30 and } \\
\text { PND55-EOS or PND55-EOS }\end{array}$ & 1 oral dose, $10 \mathrm{mg}$ DMBA at PND48 & $\begin{array}{l}\text { Tumor onset delayed only in group fed genistein PND15-30 and PND55-EOS compared } \\
\text { to control diet. No significant difference in tumor incidence }\end{array}$ & [70] \\
\hline rat & $2 \mathrm{mg} / \mathrm{kg}$ body weight, genistein orally, PND42-EOS & $\begin{array}{l}1 \text { oral dose, } 80 \mathrm{mg} / \mathrm{kg} \text { body weight } \\
\text { DMBA at PND55 }\end{array}$ & Tumor incidence and size significantly reduced in genistein group compared to controls & [71] \\
\hline rat & $\begin{array}{l}3.24 \mathrm{mg} \text { total isoflavones/g protein in diet of lean or } \\
\text { obese rats, PND42-EOS }\end{array}$ & $\begin{array}{l}1 \text { oral dose, } 65 \mathrm{mg} / \mathrm{kg} \text { body weight } \\
\text { DMBA at PND50 }\end{array}$ & $\begin{array}{l}\text { Tumor incidence significantly reduced in lean soy fed rats vs lean casein fed rats yet } \\
\text { tumor incidence significantly higher in obese soy-fed rats vs obese casein fed rats. No } \\
\text { significant differences in tumor onset or multiplicity }\end{array}$ & [72] \\
\hline rat & $\begin{array}{l}\text { Genistein } 20 \mathrm{mg} / \mathrm{kg} \text { body weight, daidzein } 20 \mathrm{mg} / \mathrm{kg} \\
\text { body weight or genistein + daidzein } 20 \mathrm{mg} / \mathrm{kg} \text { each), } \\
\text { oral } 1 \text { week before DMBA-EOS }\end{array}$ & $\begin{array}{c}1 \text { injection, } 25 \text { mg DMBA, exact age not } \\
\text { defined }\end{array}$ & $\begin{array}{l}\text { Genistein alone, daidzein alone and the combination significantly reduced tumor size } \\
\text { compared to control mice. Tumor incidence appeared to be reduced, especially in } \\
\text { combination group but no significance was indicated. }\end{array}$ & [73] \\
\hline rat & $\begin{array}{l}\text { Isoflavone-deprived soy peptide, PND28-PND56 and } \\
\text { PND63-EOS }\end{array}$ & $\begin{array}{l}1 \text { oral dose, } 50 \mathrm{mg} / \mathrm{kg} \text { body weight } \\
\text { DMBA at PND56 }\end{array}$ & $\begin{array}{l}\text { Tumor latency was significantly increased, and tumor size and multiplicity were } \\
\text { significantly decreased in isoflavone-deprived soy group vs control group }\end{array}$ & [74] \\
\hline rat & Soy milk PND50-EOS & 1 oral dose, $5 \mathrm{mg}$ DMBA at PND49 & $\begin{array}{l}\text { Tumor incidence significantly higher in soy milk group compared to water group; no } \\
\text { significant differences in tumor multiplicity or size }\end{array}$ & [75] \\
\hline rat & $20 \%$ soy protein, PND25-EOS & $\begin{array}{l}1 \text { oral dose, } 80 \mathrm{mg} / \mathrm{kg} \text { body weight } \\
\text { DMBA at PND50 }\end{array}$ & $\begin{array}{l}\text { Tumor onset significantly delayed, and tumor multiplicity significantly reduced in soy } \\
\text { group vs control group but no difference in tumor incidence at study endpoint }\end{array}$ & [76] \\
\hline rat & $\begin{array}{l}\text { Soy-free diet with } 0.35 \% \text { or } 0.7 \%(w / w) \text { SOYSELECT } \\
(12 \% \text { isoflavones and } 35 \% \text { saponins), PND21-EOS }\end{array}$ & $\begin{array}{l}1 \text { oral dose, } 80 \mathrm{mg} / \mathrm{kg} \text { body weight } \\
\text { DMBA at PND50 }\end{array}$ & No significant differences observed at study endpoint & [77] \\
\hline rat & $0.03,0.4$ or $0.81 \mathrm{mg} / \mathrm{g}$ diet isoflavones, PND36-EOS & 1 oral dose, $10 \mathrm{mg}$ DMBA at PND50 & No significant differences in tumor incidence, onset, multiplicity or burden & [78] \\
\hline rat & $\begin{array}{c}200 \mathrm{mg} / \mathrm{kg} \text { diet genistein, } 200 \mathrm{mg} / \mathrm{kg} \text { diet daidzein, } 100 \\
\mathrm{mg} / \mathrm{kg} \text { diet each of genistein + daidzein, } 160 \mathrm{~g} / \mathrm{kg} \text { diet } \\
\text { SPI or } 160 \mathrm{~g} / \mathrm{kg} \text { diet SPI depleted of isoflavones, } \\
\text { PND43-EOS }\end{array}$ & 1 oral dose, $15 \mathrm{mg}$ DMBA at PND50 & $\begin{array}{l}\text { Tumor multiplicity significantly reduced in daidzein and both SPI diets; no significant } \\
\text { difference in tumor incidence, mean latency or size in any of the diets }\end{array}$ & [79] \\
\hline rat & $\begin{array}{l}1 \mathrm{mg} / \mathrm{kg} \text { body weight genistein injected daily, } \\
\text { PND45-EOS }\end{array}$ & $\begin{array}{l}1 \text { injection, } 40 \mathrm{mg} / \mathrm{kg} \text { body weight } \\
\text { NMU at PND45 }\end{array}$ & Tumor multiplicity and size significantly elevated in genistein group vs control group & [80] \\
\hline rat & $\begin{array}{l}0.03 \text { or } 1 \mathrm{mg} / \mathrm{g} \text { of genistein in soy free diet or soy } \\
\text { containing basal diet PND28-EOS }\end{array}$ & $\begin{array}{l}\text { Oral, } 10^{-3} \mathrm{M} \text { EMS in drinking water, } \\
\text { PND28-PND112 }\end{array}$ & no significance difference in tumor incidence, size or latency compared to control group & [81] \\
\hline rat & $\begin{array}{l}100 \mathrm{~g} \text { soymilk powder } / \mathrm{kg} \text { diet alone or with } 2 \mathrm{~g} / \mathrm{kg} \text { diet } \\
\text { Lactobacillus casei in a high fat diet, PND35-EOS. }\end{array}$ & $\begin{array}{c}\text { oral, } 85 \mathrm{mg} / \mathrm{kg} \text { PhIP, } 4 \text { x/week for } 2 \\
\text { weeks, PND42-56 }\end{array}$ & $\begin{array}{l}\text { according to Table 2, no significant differences in tumor incidence, multiplicity or size in } \\
\text { soymilk vs control, however Figure } 1 \text { indicates that tumor multiplicity significantly } \\
\text { reduced at study endpoint. The combination of soymilk and Lactobacillus casei } \\
\text { significantly reduced tumor multiplicity }\end{array}$ & [82] \\
\hline mouse & Soybean diet ( $40 \%$ soybean meal), PND49-EOS & $\begin{array}{l}\text { MMTV-neu, low estrogen } \\
\text { (ovariectomy), normal estrogen } \\
\text { (untreated), and high estrogen } \\
\text { (estradiol injection) }\end{array}$ & $\begin{array}{l}\text { Tumor incidence significantly increased in soy-fed, low estrogen group but tumor } \\
\text { incidence significantly reduced in soy-fed, high estrogen group. No significant differences } \\
\text { in tumor latency or size }\end{array}$ & [83] \\
\hline
\end{tabular}


Table 1. Cont.

\begin{tabular}{|c|c|c|c|c|}
\hline Species & Isoflavone Diet/Timing & Tumor Inducer & Main Finding & Refs \\
\hline mouse & $21.7 \%$ soy protein isolate, $\mathrm{PND} 60-\mathrm{EOS}$ & $\begin{array}{l}\text { MMTV-neu (did not consider } E R \Delta 3 / \text { neu } \\
\text { mice) }\end{array}$ & $\begin{array}{l}\text { No significant effect on tumor incidence or latency in soy-fed MMTV-neu mice compared } \\
\text { to MMTV-neu mice fed a control diet }\end{array}$ & [84] \\
\hline mouse & $\begin{array}{l}0.004 \%, 0.02 \% \text { or } 0.06 \% \mathrm{wt} / \mathrm{wt} \text { Prevastein }(46.19 \% \\
\text { wt } / \mathrm{wt} \text { isoflavones), PND25-EOS }\end{array}$ & $\begin{array}{l}\text { MMTV-neu fed a Western diet (high fat, } \\
\text { moderate fiber, low calcium) }\end{array}$ & $\begin{array}{l}\text { Significant increase in tumor multiplicity and size in highest isoflavone group compared } \\
\text { to control group; no differences in medium or low isoflavone group and no significant } \\
\text { differences in tumor incidence between any of the groups }\end{array}$ & [85] \\
\hline mouse & Purina 5001 (soy diet), PND28-EOS & $\begin{array}{l}\text { MMTV-neu implanted with } 0.5 \mathrm{mg}, \\
\text { 60-day constant release estrogen pellet }\end{array}$ & $\begin{array}{l}\text { Tumor onset significantly delayed in soy group for both placebo and estrogen pellet mice } \\
\text { vs control mice; no significance different in tumor incidence was reported }\end{array}$ & [86] \\
\hline mouse & $\begin{array}{c}250 \mathrm{mg} / \mathrm{kg} \text { genistein, } 250 \mathrm{mg} / \mathrm{kg} \text { daidzein, NovaSoy, } \\
\text { PND56-EOS }\end{array}$ & $\begin{array}{l}\text { MMTV-neu, } 1 \text { pregnancy and } 2 \text { weeks } \\
\text { of lactation }\end{array}$ & $\begin{array}{c}\text { Tumor latency delayed in all isoflavone groups, tumor growth, incidence, multiplicity and } \\
\text { size not affected }\end{array}$ & [87] \\
\hline mouse & $\begin{array}{l}\text { Supro } 670 \text { with low or high isoflavone ( } 0.2 \text { and } 1.81 \\
\text { mg isoflavone/g protein isolate), PND28-EOS }\end{array}$ & MMTV-neu on high fat diet & No significant difference in tumor incidence, onset, multiplicity or size & [91] \\
\hline mouse & $430 \mathrm{mg}$ isoflavones $/ \mathrm{kg}$ diet, PND21-EOS & MMTV-Wnt1 & Tumor incidence and latency reduced in isoflavone group & [88] \\
\hline mouse & $250 \mathrm{mg} / \mathrm{kg}$ genistein, PND28-EOS & C(3)1-SV40 & No effect on tumor incidence or growth rate & [89] \\
\hline mouse & $32 \mathrm{mg} / \mathrm{kg}$ or $972 \mathrm{mg} / \mathrm{kg}$ isoflavones, PND22-EOS & MT- $h \mathrm{GH}$ & Tumor latency reduced, and tumor size increased in high isoflavone group & [90] \\
\hline
\end{tabular}

PND = post-natal day; EOS = end of study; DMBA = 7,12-Dimethylbenzathracene; NMU = N-methyl- $N$-nitrosourea; PhIP = 2-amino-1-methyl-6-phenylimidazo[4,5-b]pyridine. 
Genistein is the most studied individual soy isoflavone as it is the predominant isoflavone in soy and it can bind to estrogen receptors [92]. When evaluating only those studies that utilized purified genistein, eight studies [69-71,73,79-81,87,89] examined the impact of postnatal genistein administration on mammary tumor development with six of these studies performed on rats [69-71,73,79-81] and two in mice $[87,89]$. Three of the studies evaluating genistein in rats demonstrated some protective effect such as increased tumor latency or decreased tumor size [70,71,73]. Only one study demonstrated a significant decrease in tumor incidence [71]; however, a second study found a decrease in tumor multiplicity [74]. Of the two studies evaluating postnatal genistein administration in transgenic mice, one study observed an increase in tumor latency but no significant effect on tumor size, incidence or multiplicity [87], while the second study found no significant differences in tumor incidence or growth rate [89].

\section{Mammary Tumor Development Following Lifetime Soy Isoflavone Administration}

Fewer studies have evaluated the benefits of lifetime soy isoflavone exposure in rodent models of mammary tumor development and these studies are summarized in Table 2. Lifetime soy/isoflavone exposure was defined as soy/isoflavone administration during gestation, lactation and postnatal development. Only two studies using chemical induction of mammary tumors were found and both utilized NMU. While one study demonstrated a significant reduction in tumor incidence and prolonged tumor latency [93], the other study found no significant difference in tumor incidence [94].

Table 2. Lifetime Soy/Isoflavone Administration.

\begin{tabular}{|c|c|c|c|c|}
\hline Species & Isoflavone Diet/Timing & Tumor Inducer & Main Finding & Refs \\
\hline rat & ISP, gestation day $4-\mathrm{EOS}^{1}$ & $\begin{array}{l}1 \text { injection of } 50 \mathrm{mg} / \mathrm{kg} \text { body } \\
\text { weight NMU at PND50 }\end{array}$ & $\begin{array}{l}\text { Tumor incidence reduced, and } \\
\text { latency increased in SPI group; } \\
\text { tumor multiplicity not affected }\end{array}$ & [93] \\
\hline rats & ISP, gestation day 4 -EOS & $\begin{array}{l}1 \text { injection of } 50 \mathrm{mg} / \mathrm{kg} \text { body } \\
\text { weight NMU at PND51 }\end{array}$ & $\begin{array}{l}\text { No significant differences in } \\
\text { tumor incidence or multiplicity }\end{array}$ & [94] \\
\hline mice & $\begin{array}{l}90 \mathrm{mg} / \mathrm{kg} \text { Prevastein }(46.19 \% \mathrm{wt} / \mathrm{wt} \\
\text { isoflavones) } 2 \text { weeks prior to mating-EOS }\end{array}$ & $\begin{array}{l}\text { MMTV-neu on high fat diet } \\
\text { with either corn oil or fish oil }\end{array}$ & $\begin{array}{l}\text { Decreased tumor incidence and } \\
\text { increased tumor latency in } \\
\text { isoflavone group with corn oil but } \\
\text { no significant differences in group } \\
\text { with fish oil }\end{array}$ & [96] \\
\hline mice & $\begin{array}{c}\text { Soy containing } 4 \text { RF21, breeding-weaning } \\
\text { and then } 4 \text { RF21, SPI or isoflavone poor } \\
\text { concentrate, PND21-EOS }\end{array}$ & MMTV-neu & No difference in tumor incidence & [95] \\
\hline mice & $20 \%$ ISP, breeding-EOS & $\begin{array}{l}\text { MTB-IGFIR (IGF-IR induced } \\
\text { at PND45 or PND100) }\end{array}$ & $\begin{array}{l}\text { Tumor onset reduced, and } \\
\text { incidence increased in ISP group }\end{array}$ & [66] \\
\hline
\end{tabular}

There were also three studies using transgenic mice. One study using MMTV-neu mice found that mice fed a diet containing the isoflavone-enriched product, Prevastein, had reduced tumor incidence and prolonged tumor latency in the group that were fed a high-fat diet based on corn oil, but not in the group with a diet based on fish oil. Meanwhile, the other study found no impact on tumor incidence in MMTV-neu transgenic mice fed a high soy diet compared to controls [95]. In the study using MTB-IGFIR mice, tumor incidence was increased and tumor latency was decreased in MTB-IGFIR mice fed a diet containing 20\% ISP compared to casein-fed MTB-IGFIR mice [66].

\section{Mammary Tumor Development Following Perinatal Soy Isoflavone Administration}

For this review, perinatal exposure was defined by soy or isoflavone administration between conception and weaning. Using this definition, there were six studies identified, four of which used chemical carcinogens in rats [94,97-99] and two studies that used MMTV-neu transgenic mice [91,96]. These studies are summarized in Table 3. None of the studies demonstrated a decrease in tumor incidence in soy/isoflavone treated rodents; however, three of the studies using chemical carcinogens found a decrease in tumor multiplicity $[94,98,99]$. One study using MMTV-neu transgenic mice found 
no significant difference in the tumor incidence or onset in Prevastein-treated mice compared to control mice [96] while the other study found that tumor multiplicity and size increased in the medium- and high-Prevastein groups compared to controls [91].

Table 3. Perinatal Soy/Isoflavone Administration.

\begin{tabular}{|c|c|c|c|c|}
\hline Species & Isoflavone Diet/Timing & Tumor Inducer & Main Finding & Refs \\
\hline rat & $\begin{array}{c}250 \mathrm{mg} \text { daidzein } / \mathrm{kg} \text { diet } 2 \text { week prior to } \\
\text { mating-weaning }\end{array}$ & $\begin{array}{l}1 \text { oral dose, } 40 \mathrm{mg} \text { DMBA at } \\
\text { PND50 }\end{array}$ & $\begin{array}{l}\text { No significant differences in tumor onset or } \\
\text { incidence }\end{array}$ & [97] \\
\hline rat & $\begin{array}{l}25 \text { or } 250 \mathrm{mg} \text { genistein } / \mathrm{kg} \text { diet } \\
\text { conception-weaning }\end{array}$ & $\begin{array}{c}1 \text { oral dose, } 80 \mathrm{mg} / \mathrm{kg} \text { DMBA } \\
\text { at PND50 }\end{array}$ & $\begin{array}{l}\text { Tumor multiplicity reduced in isoflavone } \\
\text { group }\end{array}$ & [98] \\
\hline rat & $\begin{array}{l}20 \text { ug genistein injected on PND7, 10, 14, } \\
\qquad 17 \text { and } 20\end{array}$ & $\begin{array}{l}1 \text { injection, } 10 \mathrm{mg} \text { DMBA at } \\
\text { PND45 }\end{array}$ & $\begin{array}{c}\text { No significant effect on tumor latency or } \\
\text { incidence but multiplicity and growth rate } \\
\text { significantly lower in genistein group vs } \\
\text { control group }\end{array}$ & [99] \\
\hline rats & SPI, gestation day 4-EOS & $\begin{array}{l}1 \text { injection of } 50 \mathrm{mg} / \mathrm{kg} \text { body } \\
\text { weight NMU at PND51 }\end{array}$ & $\begin{array}{l}\text { No significant differences in tumor incidence } \\
\text { but multiplicity significantly reduced }\end{array}$ & [94] \\
\hline mice & $\begin{array}{l}0,18,90 \text { or } 270 \mathrm{mg} / \mathrm{kg} \text { Prevastein }(46.19 \% \\
\text { wt } / \text { wt isoflavones), conception-weaning }\end{array}$ & $\begin{array}{l}\text { MMTV-neu on normal or } \\
\text { high fat diet }\end{array}$ & $\begin{array}{c}\text { No significant difference in tumor incidence } \\
\text { but tumor multiplicity and size significantly } \\
\text { increased in medium and high isoflavone } \\
\text { group }\end{array}$ & [91] \\
\hline mice & $\begin{array}{c}90 \mathrm{mg} / \mathrm{kg} \text { Prevastein }(46.19 \% \mathrm{wt} / \mathrm{wt} \\
\text { isoflavones) } 2 \text { weeks prior to } \\
\text { mating-weaning }\end{array}$ & $\begin{array}{l}\text { MMTV-neu on high fat diet } \\
\text { with either corn oil of fish oil }\end{array}$ & No differences in tumor incidence or onset & [96] \\
\hline
\end{tabular}

\section{Conclusions and Future Considerations}

The most appropriate measure of reduced breast cancer risk would be a reduction in tumor incidence (number of animals that develop mammary tumors) in rodents fed diets containing soy or isoflavones compared to rodents fed control diets. Of the 34 studies evaluated, only 5 demonstrated a significant reduction in tumor incidence in response to diets enriched with soy products or purified isoflavones. Tumor multiplicity was reduced in soy-fed mice in an additional 6 studies and thus 11 of 34 studies demonstrated that soy products or purified isoflavones reduced either the percentage of rodents that developed mammary tumors or the number of tumors that developed in each animal. When focusing on the studies that evaluated the administration of the purified soy isoflavone genistein, 4 of the 8 studies demonstrated that postnatal genistein reduced at least one tumor characteristic, with only 2 of these studies demonstrating a decrease in tumor incidence or multiplicity. Given that less than a third of the studies demonstrated a decrease in tumor incidence or multiplicity suggests that the current studies have failed to demonstrate a consistent, protective effect of soy isoflavones in preventing mammary tumor development.

Before concluding that either rodent models are unsuitable for breast cancer prevention studies or high levels of dietary soy do not reduce breast cancer risk, further research should be encouraged. However, a number of factors require careful consideration, including (i) the type of soy (unrefined/refined, fermented/unfermented, or purified isoflavones), (ii) the experimental model (mice, rats or another model such as primates), and (iii) when to initiate soy-based diets and how long these diets should be continued. Future studies should emulate the human data that most clearly implicates that the consumption of dietary soy reduces breast cancer risk, and these are the epidemiologic studies showing that lifetime/multigenerational exposure to diets containing unrefined, fermented soy products by some Asian cultures reduces breast cancer risk. Therefore, diets containing high levels of unrefined and possibly fermented soy products should be tested. The unrefined soy products would maintain most of the soybean components such as protease inhibitors, phytosterols and saponins that are typically lost during the refinement process. With respect to timing, lifetime exposure to soy-based diets should be the minimum and multigenerational exposure should be evaluated. No study investigating mammary tumor development following multigeneration soy exposure could be found, and it is possible that soy induces epigenetic alterations in the gametes of animals with lifetime soy exposure that then impacts the gene expression and tumor sensitivity of their offspring. 
The most relevant animal model is more debatable. Although non-human primates likely represent the best model, large dietary studies in non-human primates genetically altered to express relevant human oncogenes or lacking key tumor suppressor genes are not feasible and would raise ethical concerns. Therefore, genetically altered mice or rats expressing inducible, tissue-specific oncogenes or inducible, tissue-specific knockouts utilizing known human tumor suppressor genes probably represent the most appropriate model since this system (i) uses known oncogenes and tumor suppressor genes and thus the mechanisms of tumor initiation will be more relevant to human breast cancer, (ii) permits oncogene expression or tumor suppressor gene ablation in postnatal animals which presumably emulates the timing of spontaneous activation of an oncogene or loss of a tumor suppressor gene in humans, and (iii) several inducible mouse models are currently available and their genetic similarity to different human breast cancer subtypes is often known.

However, a main concern with rodent models is that rodents and humans metabolize soy isoflavones differently $[100,101]$. These alterations in metabolism influence the amount of isoflavones present in their aglycone form and the amount of daidzein that is converted to equol [101]. Only approximately $30 \%$ of the western population produces equol [102] as a product of isoflavone metabolism while equol production has been reported in 50-60\% of Asian adults [103-106]. One hundred percent of mice and rats produce equol [101]. Soy metabolism is further complicated by the fact that diets high in soy can alter the composition of the gut microbiome [107] and thus influence circulating isoflavone levels. Isoflavone levels in tissue has been poorly studied. Chang et al. (2000, genistein) evaluated the levels of genistein in rats and found genistein in a number of tissue including the mammary gland and tissue typically contain a higher percentage of the aglycone form of genistein than the plasma $[98,108]$. Only a small number of studies have evaluated isoflavone levels in human breast tissue, and the limited data suggests that isoflavones or particular metabolites do not preferentially accumulate in breast tissue [41]. Given the differences in isoflavone metabolism, future animal studies should measure plasma and tissue isoflavone levels so isoflavone levels and composition in animal models can be compared to those achievable in humans.

Funding: This research was funded by a grant from the Canadian Cancer Society Research Institute, grant number 702774" and a grant from the Canadian Institutes of Health Research, grant number OCP-137736.

Conflicts of Interest: The authors declare no conflict of interest.

\section{References}

1. Danaei, G.; Vander Hoorn, S.; Lopez, A.D.; Murray, C.J.; Ezzati, M.; Comparative Risk Assessment collaborating, g. Causes of cancer in the world: Comparative risk assessment of nine behavioural and environmental risk factors. Lancet 2005, 366, 1784-1793. [CrossRef]

2. Wu, A.H.; Lee, E.; Vigen, C. Soy isoflavones and breast cancer. Am. Soc. Clin. Oncol. Educ. Book 2013, 2013, 102-106. [CrossRef]

3. Qin, L.Q.; Xu, J.Y.; Wang, P.Y.; Hoshi, K. Soyfood intake in the prevention of breast cancer risk in women: A meta-analysis of observational epidemiological studies. J. Nutr. Sci. Vitamin 2006, 52, 428-436. [CrossRef]

4. Trock, B.J.; Hilakivi-Clarke, L.; Clarke, R. Meta-analysis of soy intake and breast cancer risk. J. Natl. Cancer Inst. 2006, 98, 459-471. [CrossRef] [PubMed]

5. Enderlin, C.A.; Coleman, E.A.; Stewart, C.B.; Hakkak, R. Dietary soy intake and breast cancer risk. Oncol. Nurs. Forum 2009, 36, 531-539. [CrossRef]

6. Dong, J.Y.; Qin, L.Q. Soy isoflavones consumption and risk of breast cancer incidence or recurrence: A meta-analysis of prospective studies. Breast Cancer Res. Treat. 2011, 125, 315-323. [CrossRef] [PubMed]

7. Chen, M.; Rao, Y.; Zheng, Y.; Wei, S.; Li, Y.; Guo, T.; Yin, P. Association between soy isoflavone intake and breast cancer risk for pre- and post-menopausal women: A meta-analysis of epidemiological studies. PLoS ONE 2014, 9, e89288. [CrossRef]

8. Xie, Q.; Chen, M.L.; Qin, Y.; Zhang, Q.Y.; Xu, H.X.; Zhou, Y.; Mi, M.T.; Zhu, J.D. Isoflavone consumption and risk of breast cancer: A dose-response meta-analysis of observational studies. Asia Pac. J. Clin. Nutr. 2013, 22, 118-127. [CrossRef] 
9. Zhao, T.T.; Jin, F.; Li, J.G.; Xu, Y.Y.; Dong, H.T.; Liu, Q.; Xing, P.; Zhu, G.L.; Xu, H.; Miao, Z.F. Dietary isoflavones or isoflavone-rich food intake and breast cancer risk: A meta-analysis of prospective cohort studies. Clin. Nutr. 2019, 38, 136-145. [CrossRef]

10. McNally, S.; Stein, T. Overview of Mammary Gland Development: A Comparison of Mouse and Human. Methods Mol. Biol. 2017, 1501, 1-17. [CrossRef]

11. Cardiff, R.D.; Wellings, S.R. The comparative pathology of human and mouse mammary glands. J. Mammary Gland Biol. Neoplasia 1999, 4, 105-122. [CrossRef]

12. Barnes, S. Effect of genistein on in vitro and in vivo models of cancer. J. Nutr. 1995, 125, 777S-783S. [CrossRef]

13. Messina, M.; Wu, A.H. Perspectives on the soy-breast cancer relation. Am. J. Clin. Nutr. 2009, 89, 1673S-1679S. [CrossRef]

14. Murkies, A.L.; Wilcox, G.; Davis, S.R. Clinical review 92: Phytoestrogens. J. Clin. Endocrinol. Metab. 1998, 83, 297-303. [CrossRef]

15. Price, K.R.; Fenwick, G.R. Naturally occurring oestrogens in foods-a review. Food Addit. Contam. 1985, 2, 73-106. [CrossRef]

16. Krizova, L.; Dadakova, K.; Kasparovska, J.; Kasparovsky, T. Isoflavones. Molecules 2019, 24, 1076. [CrossRef]

17. An, J.; Tzagarakis-Foster, C.; Scharschmidt, T.C.; Lomri, N.; Leitman, D.C. Estrogen receptor $\beta$-selective transcriptional activity and recruitment of coregulators by phytoestrogens. J. Biol. Chem. 2001, 276, 17808-17814. [CrossRef]

18. Margeat, E.; Bourdoncle, A.; Margueron, R.; Poujol, N.; Cavailles, V.; Royer, C. Ligands differentially modulate the protein interactions of the human estrogen receptors $\alpha$ and $\beta$. J. Mol. Biol. 2003, 326, 77-92. [CrossRef]

19. Kostelac, D.; Rechkemmer, G.; Briviba, K. Phytoestrogens modulate binding response of estrogen receptors $\alpha$ and $\beta$ to the estrogen response element. J. Agric. Food Chem. 2003, 51, 7632-7635. [CrossRef]

20. Rietjens, I.; Louisse, J.; Beekmann, K. The potential health effects of dietary phytoestrogens. Br. J. Pharmacol. 2017, 174, 1263-1280. [CrossRef]

21. Vitale, D.C.; Piazza, C.; Melilli, B.; Drago, F.; Salomone, S. Isoflavones: Estrogenic activity, biological effect and bioavailability. Eur. J. Drug Metab. Pharmacokinet. 2013, 38, 15-25. [CrossRef]

22. Morito, K.; Hirose, T.; Kinjo, J.; Hirakawa, T.; Okawa, M.; Nohara, T.; Ogawa, S.; Inoue, S.; Muramatsu, M.; Masamune, Y. Interaction of phytoestrogens with estrogen receptors alpha and beta. Biol. Pharm. Bull. 2001, 24, 351-356. [CrossRef]

23. Mazur, W.; Adlercreutz, H. Overview of naturally occurring endocrine-active substances in the human diet in relation to human health. Nutrition 2000, 16, 654-658. [CrossRef]

24. Omoni, A.O.; Aluko, R.E. Soybean foods and their benefits: Potential mechanisms of action. Nutr. Rev. 2005, 63, 272-283. [CrossRef]

25. Lippman, M.E.; Krueger, K.A.; Eckert, S.; Sashegyi, A.; Walls, E.L.; Jamal, S.; Cauley, J.A.; Cummings, S.R. Indicators of lifetime estrogen exposure: Effect on breast cancer incidence and interaction with raloxifene therapy in the multiple outcomes of raloxifene evaluation study participants. J. Clin. Oncol. 2001, 19, 3111-3116. [CrossRef]

26. Messina, M.; McCaskill-Stevens, W.; Lampe, J.W. Addressing the soy and breast cancer relationship: Review, commentary, and workshop proceedings. J. Natl. Cancer Inst. 2006, 98, 1275-1284. [CrossRef]

27. Setchell, K.D. Phytoestrogens: The biochemistry, physiology, and implications for human health of soy isoflavones. Am. J. Clin. Nutr. 1998, 68, 1333S-1346S. [CrossRef]

28. Kladna, A.; Berczynski, P.; Kruk, I.; Piechowska, T.; Aboul-Enein, H.Y. Studies on the antioxidant properties of some phytoestrogens. Luminescence 2016, 31, 1201-1206. [CrossRef]

29. Chae, H.S.; Xu, R.; Won, J.Y.; Chin, Y.W.; Yim, H. Molecular Targets of Genistein and Its Related Flavonoids to Exert Anticancer Effects. Int. J. Mol. Sci. 2019, 20, 2420. [CrossRef]

30. Fotsis, T.; Pepper, M.S.; Montesano, R.; Aktas, E.; Breit, S.; Schweigerer, L.; Rasku, S.; Wahala, K.; Adlercreutz, H. Phytoestrogens and inhibition of angiogenesis. Baillieres Clin. Endocrinol. Metab. 1998, 12, 649-666. [CrossRef]

31. Mukund, V.; Saddala, M.S.; Farran, B.; Mannavarapu, M.; Alam, A.; Nagaraju, G.P. Molecular docking studies of angiogenesis target protein HIF-1alpha and genistein in breast cancer. Gene 2019, 701, 169-172. [CrossRef]

32. Berndt, S.; Issa, M.E.; Carpentier, G.; Cuendet, M. A Bivalent Role of Genistein in Sprouting Angiogenesis. Planta Med. 2018, 84, 653-661. [CrossRef]

33. Lecomte, S.; Demay, F.; Ferriere, F.; Pakdel, F. Phytochemicals Targeting Estrogen Receptors: Beneficial Rather Than Adverse Effects? Int. J. Mol. Sci. 2017, 18, 1381. [CrossRef] 
34. Setchell, K.D.; Brown, N.M.; Zhao, X.; Lindley, S.L.; Heubi, J.E.; King, E.C.; Messina, M.J. Soy isoflavone phase II metabolism differs between rodents and humans: Implications for the effect on breast cancer risk. Am. J. Clin. Nutr. 2011, 94, 1284-1294. [CrossRef]

35. van der Velpen, V.; Hollman, P.C.; van Nielen, M.; Schouten, E.G.; Mensink, M.; Van't Veer, P.; Geelen, A. Large inter-individual variation in isoflavone plasma concentration limits use of isoflavone intake data for risk assessment. Eur. J. Clin. Nutr. 2014, 68, 1141-1147. [CrossRef]

36. Chang, Y.; Choue, R. Plasma pharmacokinetics and urinary excretion of isoflavones after ingestion of soy products with different aglycone/glucoside ratios in South Korean women. Nutr. Res. Pract. 2013, 7, 393-399. [CrossRef]

37. Peiroten, A.; Bravo, D.; Landete, J.M. Bacterial metabolism as responsible of beneficial effects of phytoestrogens on human health. Crit. Rev. Food Sci. Nutr. 2019, 4, 1-16. [CrossRef]

38. Rowlands, J.C.; Berhow, M.A.; Badger, T.M. Estrogenic and antiproliferative properties of soy sapogenols in human breast cancer cells in vitro. Food Chem. Toxicol. 2002, 40,1767-1774. [CrossRef]

39. Hsieh, C.C.; Hernandez-Ledesma, B.; Jeong, H.J.; Park, J.H.; de Lumen, B.O. Complementary roles in cancer prevention: Protease inhibitor makes the cancer preventive peptide lunasin bioavailable. PLoS ONE 2010, 5, e8890. [CrossRef]

40. Chatterjee, C.; Gleddie, S.; Xiao, C.W. Soybean Bioactive Peptides and Their Functional Properties. Nutrients 2018, 10, 1211. [CrossRef]

41. Huser, S.; Guth, S.; Joost, H.G.; Soukup, S.T.; Kohrle, J.; Kreienbrock, L.; Diel, P.; Lachenmeier, D.W.; Eisenbrand, G.; Vollmer, G.; et al. Effects of isoflavones on breast tissue and the thyroid hormone system in humans: A comprehensive safety evaluation. Arch. Toxicol. 2018, 92, 2703-2748. [CrossRef]

42. Barnes, S. The biochemistry, chemistry and physiology of the isoflavones in soybeans and their food products. Lymphat. Res. Biol. 2010, 8, 89-98. [CrossRef]

43. Setchell, K.D.; Cole, S.J. Variations in isoflavone levels in soy foods and soy protein isolates and issues related to isoflavone databases and food labeling. J. Agric. Food Chem. 2003, 51, 4146-4155. [CrossRef]

44. Fang, N.; Yu, S.; Badger, T.M. Comprehensive phytochemical profile of soy protein isolate. J. Agric. Food Chem. 2004, 52, 4012-4020. [CrossRef]

45. Rogers, A.E.; Lee, S.Y. Chemically-induced mammary gland tumors in rats: Modulation by dietary fat. Prog. Clin. Biol. Res. 1986, 222, 255-282.

46. Russo, J.; Gusterson, B.A.; Rogers, A.E.; Russo, I.H.; Wellings, S.R.; van Zwieten, M.J. Comparative study of human and rat mammary tumorigenesis. Lab. Invest 1990, 62, 244-278.

47. Sukumar, S.; Notario, V.; Martin-Zanca, D.; Barbacid, M. Induction of mammary carcinomas in rats by nitroso-methylurea involves malignant activation of H-ras-1 locus by single point mutations. Nature 1983, 306, 658-661. [CrossRef]

48. Zarbl, H.; Sukumar, S.; Arthur, A.L.; Martin-Zanca, D.; Barbacid, M. Activation of H-ras-1 oncogenes by chemical carcinogens. Basic Life Sci. 1986, 38, 385-397.

49. Zarbl, H.; Sukumar, S.; Arthur, A.V.; Martin-Zanca, D.; Barbacid, M. Direct mutagenesis of Ha-ras-1 oncogenes by $\mathrm{N}$-nitroso-N-methylurea during initiation of mammary carcinogenesis in rats. Nature 1985, 315, 382-385. [CrossRef]

50. Dandekar, S.; Sukumar, S.; Zarbl, H.; Young, L.J.; Cardiff, R.D. Specific activation of the cellular Harvey-ras oncogene in dimethylbenzanthracene-induced mouse mammary tumors. Mol. Cell Biol. 1986, 6, 4104-4108. [CrossRef]

51. Abba, M.C.; Zhong, Y.; Lee, J.; Kil, H.; Lu, Y.; Takata, Y.; Simper, M.S.; Gaddis, S.; Shen, J.; Aldaz, C.M. DMBA induced mouse mammary tumors display high incidence of activating Pik3caH1047 and loss of function Pten mutations. Oncotarget 2016, 7, 64289-64299. [CrossRef]

52. Choi, Y.W.; Henrard, D.; Lee, I.; Ross, S.R. The mouse mammary tumor virus long terminal repeat directs expression in epithelial and lymphoid cells of different tissues in transgenic mice. J. Virol. 1987, 61, 3013-3019.

53. Wagner, K.U.; McAllister, K.; Ward, T.; Davis, B.; Wiseman, R.; Hennighausen, L. Spatial and temporal expression of the Cre gene under the control of the MMTV-LTR in different lines of transgenic mice. Transgenic Res. 2001, 10, 545-553. [CrossRef]

54. Yang, G.; Park, S.; Cao, G.; Goltsov, A.; Ren, C.; Truong, L.D.; Demayo, F.; Thompson, T.C. MMTV promoter-regulated caveolin-1 overexpression yields defective parenchymal epithelia in multiple exocrine organs of transgenic mice. Exp. Mol. Pathol. 2010, 89, 9-19. [CrossRef] 
55. Muller, W.J.; Sinn, E.; Pattengale, P.K.; Wallace, R.; Leder, P. Single-step induction of mammary adenocarcinoma in transgenic mice bearing the activated c-neu oncogene. Cell 1988, 54, 105-115. [CrossRef]

56. Bouchard, L.; Lamarre, L.; Tremblay, P.J.; Jolicoeur, P. Stochastic appearance of mammary tumors in transgenic mice carrying the MMTV/c-neu oncogene. Cell 1989, 57, 931-936. [CrossRef]

57. Guy, C.T.; Cardiff, R.D.; Muller, W.J. Activated neu induces rapid tumor progression. J. Biol. Chem. 1996, 271, 7673-7678. [CrossRef]

58. Herschkowitz, J.I.; Simin, K.; Weigman, V.J.; Mikaelian, I.; Usary, J.; Hu, Z.; Rasmussen, K.E.; Jones, L.P.; Assefnia, S.; Chandrasekharan, S.; et al. Identification of conserved gene expression features between murine mammary carcinoma models and human breast tumors. Genome Biol. 2007, 8, R76. [CrossRef]

59. Truss, M.; Bartsch, J.; Mows, C.; Chavez, S.; Beato, M. Chromatin structure of the MMTV promoter and its changes during hormonal induction. Cell Mol. Neurobiol. 1996, 16, 85-101. [CrossRef]

60. Cato, A.C.; Henderson, D.; Ponta, H. The hormone response element of the mouse mammary tumour virus DNA mediates the progestin and androgen induction of transcription in the proviral long terminal repeat region. EMBO J. 1987, 6, 363-368. [CrossRef]

61. Ham, J.; Thomson, A.; Needham, M.; Webb, P.; Parker, M. Characterization of response elements for androgens, glucocorticoids and progestins in mouse mammary tumour virus. Nucleic Acids Res. 1988, 16, 5263-5276. [CrossRef]

62. Truss, M.; Chalepakis, G.; Beato, M. Interplay of steroid hormone receptors and transcription factors on the mouse mammary tumor virus promoter. J. Steroid Biochem. Mol. Biol. 1992, 43, 365-378. [CrossRef]

63. Maroulakou, I.G.; Anver, M.; Garrett, L.; Green, J.E. Prostate and mammary adenocarcinoma in transgenic mice carrying a rat C3(1) simian virus 40 large tumor antigen fusion gene. Proc. Natl. Acad. Sci. USA 1994, 91, 11236-11240. [CrossRef]

64. Tornell, J.; Rymo, L.; Isaksson, O.G. Induction of mammary adenocarcinomas in metallothionein promoter-human growth hormone transgenic mice. Int. J. Cancer 1991, 49, 114-117. [CrossRef]

65. Jones, R.A.; Campbell, C.I.; Gunther, E.J.; Chodosh, L.A.; Petrik, J.J.; Khokha, R.; Moorehead, R.A. Transgenic overexpression of IGF-IR disrupts mammary ductal morphogenesis and induces tumor formation. Oncogene 2007, 26, 1636-1644. [CrossRef]

66. Watson, K.L.; Stalker, L.; Jones, R.A.; Moorehead, R.A. High levels of dietary soy decrease mammary tumor latency and increase incidence in MTB-IGFIR transgenic mice. BMC Cancer 2015, 15, 37. [CrossRef]

67. Franks, S.E.; Campbell, C.I.; Barnett, E.F.; Siwicky, M.D.; Livingstone, J.; Cory, S.; Moorehead, R.A. Transgenic IGF-IR overexpression induces mammary tumors with basal-like characteristics while IGF-IR independent mammary tumors express a claudin-low gene signature. Oncogene 2012, 31, 3298-3309. [CrossRef]

68. Jones, R.A.; Watson, K.L.; Campbell, C.I.; Moorehead, R.A. IGF-IR mediated mammary tumorigenesis is enhanced during pubertal development. PLoS ONE 2014, 9, e108781. [CrossRef]

69. Manjanatha, M.G.; Shelton, S.; Bishop, M.E.; Lyn-Cook, L.E.; Aidoo, A. Dietary effects of soy isoflavones daidzein and genistein on 7,12-dimethylbenz[a]anthracene-induced mammary mutagenesis and carcinogenesis in ovariectomized Big Blue transgenic rats. Carcinogenesis 2006, 27, 2555-2564. [CrossRef]

70. Zhang, X.; Cook, K.L.; Warri, A.; Cruz, I.M.; Rosim, M.; Riskin, J.; Helferich, W.; Doerge, D.; Clarke, R.; Hilakivi-Clarke, L. Lifetime Genistein Intake Increases the Response of Mammary Tumors to Tamoxifen in Rats. Clin. Cancer Res. 2017, 23, 814-824. [CrossRef]

71. Sahin, K.; Tuzcu, M.; Sahin, N.; Akdemir, F.; Ozercan, I.; Bayraktar, S.; Kucuk, O. Inhibitory effects of combination of lycopene and genistein on 7,12- dimethyl benz(a)anthracene-induced breast cancer in rats. Nutr. Cancer 2011, 63, 1279-1286. [CrossRef]

72. Hakkak, R.; Shaaf, S.; Jo, C.H.; Macleod, S.; Korourian, S. Effects of high-isoflavone soy diet vs. casein protein diet and obesity on DMBA-induced mammary tumor development. Oncol. Letters 2011, 2, 29-36. [CrossRef]

73. Pugalendhi, P.; Manoharan, S. Chemopreventive potential of genistein and daidzein in combination during 7,12-dimethylbenz[a]anthracene (DMBA) induced mammary carcinogenesis in Sprague-Dawley rats. Pak. J. Biol. Sci. 2010, 13, 279-286. [CrossRef]

74. Park, K.; Choi, K.; Kim, H.; Kim, K.; Lee, M.H.; Lee, J.H.; Kim Rim, J.C. Isoflavone-deprived soy peptide suppresses mammary tumorigenesis by inducing apoptosis. Exp. Mol. Med. 2009, 41, 371-381. [CrossRef]

75. Qin, L.Q.; Xu, J.Y.; Tezuka, H.; Wang, P.Y.; Hoshi, K. Commercial soy milk enhances the development of 7,12-dimethylbenz(a)anthracene-induced mammary tumors in rats. In Vivo 2007, 21, 667-671. 
76. Mukhopadhyay, S.; Ballard, B.R.; Mukherjee, S.; Kabir, S.M.; Das, S.K. Beneficial effects of soy protein in the initiation and progression against dimethylbenz [a] anthracene-induced breast tumors in female rats. Mol. Cell Biochem. 2006, 290, 169-176. [CrossRef]

77. Gallo, D.; Giacomelli, S.; Cantelmo, F.; Zannoni, G.F.; Ferrandina, G.; Fruscella, E.; Riva, A.; Morazzoni, P.; Bombardelli, E.; Mancuso, S.; et al. Chemoprevention of DMBA-induced mammary cancer in rats by dietary soy. Breast Cancer Res. Treat. 2001, 69, 153-164. [CrossRef]

78. Appelt, L.C.; Reicks, M.M. Soy induces phase II enzymes but does not inhibit dimethylbenz[a]anthracene-induced carcinogenesis in female rats. J. Nutr. 1999, 129, 1820-1826. [CrossRef]

79. Constantinou, A.I.; Lantvit, D.; Hawthorne, M.; Xu, X.; van Breemen, R.B.; Pezzuto, J.M. Chemopreventive effects of soy protein and purified soy isoflavones on DMBA-induced mammary tumors in female Sprague-Dawley rats. Nutr. Cancer 2001, 41, 75-81. [CrossRef]

80. Kijkuokool, P.; Parhar, I.S.; Malaivijitnond, S. Genistein enhances N-nitrosomethylurea-induced rat mammary tumorigenesis. Cancer Lett. 2006, 242, 53-59. [CrossRef]

81. Ono, M.; Koga, T.; Ueo, H.; Nakano, S. Effects of dietary genistein on hormone-dependent rat mammary carcinogenesis induced by ethyl methanesulphonate. Nutr. Cancer 2012, 64, 1204-1210. [CrossRef]

82. Kaga, C.; Takagi, A.; Kano, M.; Kado, S.; Kato, I.; Sakai, M.; Miyazaki, K.; Nanno, M.; Ishikawa, F.; Ohashi, Y.; et al. Lactobacillus casei Shirota enhances the preventive efficacy of soymilk in chemically induced breast cancer. Cancer Sci. 2013, 104, 1508-1514. [CrossRef]

83. Zhang, G.P.; Han, D.; Liu, G.; Gao, S.G.; Cai, X.Q.; Duan, R.H.; Feng, X.S. Effects of soy isoflavone and endogenous oestrogen on breast cancer in MMTV-erbB2 transgenic mice. J. Int. Med. Res. 2012, 40, 2073-2082. [CrossRef]

84. Davis, V.L.; Shaikh, F.; Gallagher, K.M.; Villegas, M.; Rea, S.L.; Cline, J.M.; Hughes, C.L. Inhibition of Neu-induced mammary carcinogenesis in transgenic mice expressing ERDelta3, a dominant negative estrogen receptor alpha variant. Horm. Cancer 2012, 3, 227-239. [CrossRef]

85. Thomsen, A.R.; Mortensen, A.; Breinholt, V.M.; Lindecrona, R.H.; Penalvo, J.L.; Sorensen, I.K. Influence of Prevastein, an isoflavone-rich soy product, on mammary gland development and tumorigenesis in Tg.NK (MMTV/c-neu) mice. Nutr. Cancer 2005, 52, 176-188. [CrossRef]

86. Yang, X.; Edgerton, S.M.; Kosanke, S.D.; Mason, T.L.; Alvarez, K.M.; Liu, N.; Chatterton, R.T.; Liu, B.; Wang, Q.; Kim, A.; et al. Hormonal and dietary modulation of mammary carcinogenesis in mouse mammary tumor virus-c-erbB-2 transgenic mice. Cancer Res. 2003, 63, 2425-2433.

87. Jin, Z.; MacDonald, R.S. Soy isoflavones increase latency of spontaneous mammary tumors in mice. J. Nutr. 2002, 132, 3186-3190. [CrossRef]

88. Rahal, O.M.; Machado, H.L.; Montales, M.T.; Pabona, J.M.; Heard, M.E.; Nagarajan, S.; Simmen, R.C. Dietary suppression of the mammary CD29(hi)CD24(+) epithelial subpopulation and its cytokine/chemokine transcriptional signatures modifies mammary tumor risk in MMTV-Wnt1 transgenic mice. Stem Cell Res. 2013, 11, 1149-1162. [CrossRef]

89. Paul, B.; Li, Y.; Tollefsbol, T.O. The Effects of Combinatorial Genistein and Sulforaphane in Breast Tumor Inhibition: Role in Epigenetic Regulation. Int. J. Mol. Sci. 2018, 19, 1754. [CrossRef]

90. Hickey, J.; Bartke, A.; Winters, T.; Henry, N.; Banz, W. Effects of soy protein and soy phytochemicals on mammary tumor development in female transgenic mice overexpressing human pituitary growth hormone. J. Med. Food 2005, 8, 556-559. [CrossRef]

91. Luijten, M.; Thomsen, A.R.; van den Berg, J.A.; Wester, P.W.; Verhoef, A.; Nagelkerke, N.J.; Adlercreutz, H.; van Kranen, H.J.; Piersma, A.H.; Sorensen, I.K.; et al. Effects of soy-derived isoflavones and a high-fat diet on spontaneous mammary tumor development in Tg.NK (MMTV/c-neu) mice. Nutr. Cancer 2004, 50, 46-54. [CrossRef]

92. Lamartiniere, C.A.; Cotroneo, M.S.; Fritz, W.A.; Wang, J.; Mentor-Marcel, R.; Elgavish, A. Genistein chemoprevention: Timing and mechanisms of action in murine mammary and prostate. J. Nutr. 2002, 132, 552S-558S. [CrossRef]

93. Simmen, R.C.; Eason, R.R.; Till, S.R.; Chatman, L., Jr.; Velarde, M.C.; Geng, Y.; Korourian, S.; Badger, T.M. Inhibition of NMU-induced mammary tumorigenesis by dietary soy. Cancer Lett. 2005, 224, 45-52. [CrossRef] 
94. Su, Y.; Eason, R.R.; Geng, Y.; Till, S.R.; Badger, T.M.; Simmen, R.C. In utero exposure to maternal diets containing soy protein isolate, but not genistein alone, protects young adult rat offspring from NMU-induced mammary tumorigenesis. Carcinogenesis 2007, 28, 1046-1051. [CrossRef]

95. Chiesa, G.; Rigamonti, E.; Lovati, M.R.; Disconzi, E.; Soldati, S.; Sacco, M.G.; Cato, E.M.; Patton, V.; Scanziani, E.; Vezzoni, P.; et al. Reduced mammary tumor progression in a transgenic mouse model fed an isoflavone-poor soy protein concentrate. Mol. Nutr. Food Res. 2008, 52, 1121-1129. [CrossRef]

96. Luijten, M.; Verhoef, A.; Dormans, J.A.; Beems, R.B.; Cremers, H.W.; Nagelkerke, N.J.; Adlercreutz, H.; Penalvo, J.L.; Piersma, A.H. Modulation of mammary tumor development in Tg.NK (MMTV/c-neu) mice by dietary fatty acids and life stage-specific exposure to phytoestrogens. Reprod. Toxicol. 2007, 23, 407-413. [CrossRef]

97. Lamartiniere, C.A.; Wang, J.; Smith-Johnson, M.; Eltoum, I.E. Daidzein: Bioavailability, potential for reproductive toxicity, and breast cancer chemoprevention in female rats. Toxicol. Sci. 2002, 65, 228-238. [CrossRef]

98. Fritz, W.A.; Coward, L.; Wang, J.; Lamartiniere, C.A. Dietary genistein: Perinatal mammary cancer prevention, bioavailability and toxicity testing in the rat. Carcinogenesis 1998, 19, 2151-2158. [CrossRef]

99. Hilakivi-Clarke, L.; Onojafe, I.; Raygada, M.; Cho, E.; Skaar, T.; Russo, I.; Clarke, R. Prepubertal exposure to zearalenone or genistein reduces mammary tumorigenesis. Br. J. Cancer 1999, 80, 1682-1688. [CrossRef]

100. Mortensen, A.; Kulling, S.E.; Schwartz, H.; Rowland, I.; Ruefer, C.E.; Rimbach, G.; Cassidy, A.; Magee, P.; Millar, J.; Hall, W.L.; et al. Analytical and compositional aspects of isoflavones in food and their biological effects. Mol. Nutr. Food Res. 2009, 53 (Suppl. 2), S266-S309. [CrossRef]

101. Soukup, S.T.; Helppi, J.; Muller, D.R.; Zierau, O.; Watzl, B.; Vollmer, G.; Diel, P.; Bub, A.; Kulling, S.E. Phase II metabolism of the soy isoflavones genistein and daidzein in humans, rats and mice: A cross-species and sex comparison. Arch. Toxicol. 2016, 90, 1335-1347. [CrossRef]

102. Rafii, F. The role of colonic bacteria in the metabolism of the natural isoflavone daidzin to equol. Metabolites 2015, 5, 56-73. [CrossRef]

103. Watanabe, S.; Yamaguchi, M.; Sobue, T.; Takahashi, T.; Miura, T.; Arai, Y.; Mazur, W.; Wahala, K.; Adlercreutz, H. Pharmacokinetics of soybean isoflavones in plasma, urine and feces of men after ingestion of $60 \mathrm{~g}$ baked soybean powder (kinako). J. Nutr. 1998, 128, 1710-1715. [CrossRef]

104. Arai, Y.; Watanabe, S.; Kimira, M.; Shimoi, K.; Mochizuki, R.; Kinae, N. Dietary intakes of flavonols, flavones and isoflavones by Japanese women and the inverse correlation between quercetin intake and plasma LDL cholesterol concentration. J. Nutr. 2000, 130, 2243-2250. [CrossRef]

105. Akaza, H.; Miyanaga, N.; Takashima, N.; Naito, S.; Hirao, Y.; Tsukamoto, T.; Fujioka, T.; Mori, M.; Kim, W.J.; Song, J.M.; et al. Comparisons of percent equol producers between prostate cancer patients and controls: Case-controlled studies of isoflavones in Japanese, Korean and American residents. Jpn. J. Clin. Oncol. 2004, 34, 86-89. [CrossRef]

106. Song, K.B.; Atkinson, C.; Frankenfeld, C.L.; Jokela, T.; Wahala, K.; Thomas, W.K.; Lampe, J.W. Prevalence of daidzein-metabolizing phenotypes differs between Caucasian and Korean American women and girls. J. Nutr. 2006, 136, 1347-1351. [CrossRef]

107. Brink, L.; Chintapalli, S.; Mercer, K.; Piccolo, B.; Adams, S.; Bowlin, A.; Matazel, K.; Shankar, K.; Badger, T.; Andres, A.; et al. Early Postnatal Diet Differentially Affects the Fecal Microbiome and Metabolome (FS04-02-19). Curr. Dev. Nutr. 2019, 3 (Suppl. 1). [CrossRef]

108. Chang, H.C.; Churchwell, M.I.; Delclos, K.B.; Newbold, R.R.; Doerge, D.R. Mass spectrometric determination of genistein tissue distribution in diet-exposed Sprague-Dawley rats. J. Nutr. 2000, 130, 1963-1970. [CrossRef]

(C) 2019 by the author. Licensee MDPI, Basel, Switzerland. This article is an open access article distributed under the terms and conditions of the Creative Commons Attribution (CC BY) license (http://creativecommons.org/licenses/by/4.0/). 